\title{
МОДЕРНІЗАЦІЯ ОСВІТНЬОГО ПРОЦЕСУ НА КАФЕДРІ ГІСТОЛОГІї, ЦИТОЛОГІї ТА ЕМБРІОЛОГІї
}

\author{
В. К. Сирцов, С. С. Ключко, А. І. Хитрик, М. І. Завгородня, М. Л. Таврог \\ Запорізький державний медичний університет МОЗ України
}

\section{MODERNIZATION OF THE EDUCATIONAL PROCESS AT THE DEPARTMENT OF HISTOLOGY, CYTOLOGY AND EMBRYOLOGY}

\author{
V. K. Syrtsov, S. S. Kliuchko, A. I. Khytryk, M. I. Zavhorodnya, M. L. Tavroh \\ Zaporizhian State Medical University of MPH of Ukraine
}

\begin{abstract}
В умовах реалізації основних освітніх програм у рамках Болонського процесу важливе місце набуває інтерактивна технологія викладання. У статті за допомогою системного аналізу, анкетування та опитування студентів і викладачів досліджено сучасні методики викладання дисципліни, які впроваджуються в освітній процес на кафедрі гістології, цитології та ембріології ЗДМУ. Запропоновані інтерактивні методи створюють комфортні умови навчання, за яких студент відчуває свою успішність, інтелектуальну спроможність, що робить більш продуктивним сам процес навчання.

In the context of the implementation of major educational programs under the Bologna Process an interactive technology teaching gets a significant place. The article, using the system analysis, questionnaires and interviews with students and teachers, studied, modern methods of teaching, which are being implemented in the educational process at the Department of Histology, Cytology and Embryology of ZSMU. The proposed interactive methods create a comfortable learning environment in which students feel their success, intellectual consistency, making productive learning process itself.
\end{abstract}

Вступ. У даний час, у зв’язку з активними науковими дослідженнями і просуванням медичної науки вперед, з величезною кількістю інформації, яку необхідно засвоїти та інтегрувати сучасному студенту, актуальним завданням медичної освітньої системи є розробка та дослідження нових систем викладання матеріалу, що дозволяють сприйняти, зрозуміти, систематизувати і запам'ятати інформацію в необхідному обсязі в обмеженому часовому діапазоні [1-3]. Саме такий підхід дозволить на наступних етапах навчання в медичному вузі повноцінно оволодіти базовими знаннями i, що вкрай важливо, пройти становлення і розвиток в якості молодого лікаря, повноцінно оволодіти професією і вирости в конкурентоспроможного фахівця міжнародного рівня [4]. У зв’язку з вищесказаним, на нашій кафедрі широко застосовуються і досліджуються інтерактивні методи викладання дисципліни [5].

Основна частина. Метою роботи стало дослідження застосування інтерактивних методів викладання на базі кафедри гістології цитології та

(с В. К. Сирцов, С. С. Ключко, А. І. Хитрик та ін. ембріології ЗДМУ, а також систематизація методів і оцінка їхньої ефективності. Основними методами дослідження були об'єктивна оцінка засвоєння знань студентами шляхом підсумкової атестації, оцінка ефективності методик старшим викладацьким складом, студентами шляхом опитування, анкетування.

У педагогіці успішно співіснують кілька моделей навчання: пасивна - студент виступає в ролі “об’єкта” навчання (слухає й дивиться); активна студент виступає “суб’ єктом” навчання (самостійна робота, творчі завдання); інтерактивна - взаємодія. Значуще місце набуває принципово інша по організації пізнавальної діяльності студента інтерактивна технологія, яка дозволяє створити комфортні умови навчання, розвиває творчий підхід до вирішення проблеми у студента, мотивуючи його, дозволяє викладачеві ефективно організувати освітній процес в умовах кредитно-модульної системи [6].

Інтерактивне навчання - навчання, побудоване на взаємодії всіх студентів між собою і з викладачем. Ці методи найбільш відповідають особистісноорієнтованому підходу, оскільки вони припускають співнавчання (колективне, навчання у співпраці), 
причому і студенти, і викладач є суб'єктами навчального процесу. Викладач частіше виступає лише в ролі організатора процесу навчання, лідера групи, фасилітатора, творця умов для ініціативи студентів. Інтерактивне навчання засноване на прямій взаємодії учнів зі своїм досвідом і досвідом своїх друзів, оскільки більшість інтерактивних вправ звертається до досвіду самого студента, причому не тільки навчального. Нове знання, вміння формується на основі такого досвіду.

Впровадження інтерактивних методик в умовах роботи зі студентами на кафедрі гістології, цитології та ембріології ЗДМУ успішно проводиться протягом останніх років і дає підставу вважати їх перспективними і активно використовувати. Далі будуть запропоновані деякі з методик, що зарекомендували себе якнайкраще.

Заняття-конференція (ЗК). Якщо великий обсяг матеріалу, а студенти в групі слабкі і немає впевненості, що всі засвоять задане, то доцільно провести заняття у форматі конференції. В якості домашнього завдання кожному студенту дається тема для виступу (час регламентовано), причому відомості повинні бути не тільки з підручника, а також з наукових публікацій, монографій. Заняття імітує наукову конференцію: виступи, запитання, висновок, вибір кращого повідомлення.

Ситуаційні завдання. Проблемна ситуація (від грец. problema - завдання і лат. situation - положення) - ситуація, для оволодіння якою індивід або колектив повинні знайти і використовувати нові для себе засоби і методи діяльності. Згідно з нашими спостереженнями, використання ситуаційних завдань сприяє формуванню клінічного мислення студента, заохочує творчу дискусію, значно стимулює студентів і дає почуття задоволеності від своєї роботи.

Кейс-метод. Метод case-study, або метод конкретних ситуацій (від англійського case - випадок, ситуація), - метод активного проблемно-ситуаційного аналізу, заснований на навчанні шляхом вирішення конкретних завдань - ситуацій (рішення кейсів), що дозволяє застосувати теоретичні знання до вирішення практичних завдань.

Активізація творчої діяльності (АТД). Активізація творчої діяльності студентів здійснюється практично шляхом виконання творчих завдань. Так, наприклад, на нашій кафедрі виконувалися переклади наукових статей, складання тематичних кросвордів, вивчення та аналіз теоретичного матеріалу у вітчизняних та зарубіжних джерелах, виступи в наукових гуртках.
Метод заняття за принципом “снігової кулі”. “Снігова куля” - це образна назва методу проведення навчального заняття, яке починається з того, що студентам дається індивідуальний час на роздуми. Потім починається обговорення в групах по дві, чотири, вісім осіб і так доти, поки в обговоренні не візьме участь вся група. Метод має на меті дати можливість кожному члену групи висловити свою точку зору i, використовуючи ті знання і досвід, які $€$ у всієї групи, дозволяє меншими зусиллями зрівняти відмінності в здібностях членів групи.

Метод “ручка в центрі столу”. Мета методу залучити до участі всіх учасників групи, сприяє концентрації уваги і активізує студентів. Групі пропонується спільне рішення одного завдання. На один лист кожен студент записує один варіант відповіді і пересуває лист товаришеві, при цьому свою ручку пересуває в центр столу. При відсутності відповіді ручка залишається у студента. Всі відповіді обговорюються спільно, аналізуються правильні і неправильні варіанти. Аналіз і повтор правильних відповідей підвищують рівень засвоєння і запам’ятовування матеріалу.

Кожен вчить кожного. Порядок проведення: готуються картки з фактами. Викладіть будь-який факт, що відноситься до теми заняття, на картці 3 картону або аркуші паперу - по одному на кожного студента. Протягом декількох хвилин студент повинен прочитати інформацію на картці. Після прочитання попросіть учнів почати ходити по класу і знайомити зі своїм фактом зустрічних людей (по одній людині). Завдання полягає в тому, щоб поділитися своїм фактом і самому дізнатися один факт від іншого учня. Після того як студенти завершать цю вправу, спитайте їх про те, що вони дізналися від іншого учня. Оцініть знання.

Учень у ролі вчителя. Так, наприклад, викладач розбирає індивідуально зі студентом навчальний матеріал по таблиці, а потім студент розповідає цей розділ теми всій групі, “навчає” товаришів, відповідає на їхні запитання.

Мозковий штурм (МШ). Метою проведення “мозкового штурму (атаки)” є отримання від групи в короткий час великої кількості варіантів. “Мозковий штурм” може продемонструвати, що знають студенти; в ході її можуть бути запропоновані ідеї, здатні вирішити проблему, створена структура обміну поглядами на загальний досвід і висловлені побажання студентів. У ході роботи на нашій кафедрі застосовується рідко, однак заслуговує вивчення в подальшому. 
Метод малих груп (МГ). Мета: заняття в малих групах дозволяють учням набути навичок співпраці та інші важливі міжособистісні навички. Крім того, ці заняття допомагають учням навчитися вирішувати виникаючі між ними розбіжності. Чим менше часу відпущено на завершення уроку, тим менше повинен бути розмір групи. Маленькі групи більш ефективні, оскільки швидше піддаються організації, швидше працюють і надають кожному студенту більше можливостей внести в роботу свій внесок.

Висновки. Результатом застосування інтерактивних форм навчання на кафедрі гістології, цитоло-

\section{Список літератури}

1. Грубінко В. В. Індивідуальна та самостійна робота студентів в умовах кредитно-модульної системи організації навчального процесу / В. В. Грубінко // Кредитномодульна система організації навчального процесу : матеріали наук.-практ. семінару. - Тернопіль : ТДМУ, 2004. - С. 3.

2. Журавський В. С. Болонський процес: головні принципи входження в Європейський простір вищої освіти / В. С. Журавський, М. З. Згуровський. - К. : Політехніка, 2003. - 200 с.

3. Оптимізація організації контролю знань студентів з гістології, цитології та ембріології у світлі вимог Болонського процесу / Ю. М. Нерянов, В. К. Сирцов, О. В. Федосєєва [та ін.] // Галицький лікарський вісник. - 2010. - Т.17, № 2, ч. 2. - С. 108-110. гії та ембріології є: пробудження в учнів інтересу до дисципліни, ефективне засвоєння студентами навчального матеріалу, самостійний пошук учнями шляхів і варіантів вирішення поставленої навчальної задачі, навчання працювати в команді, проявляти толерантність до будь-якої точки зору, формування життєвих і професійних навичок. За умов реорганізації освітнього процесу за кредитномодульною системою навчання та впровадження інтерактивних методик проведення практичних занять слід організувати на базі профільної кафедри курси з перепідготовки викладачів з метою освоєння ними сучасних методик викладання дисципліни.

4. Медична освіта у світі та Україні / [Ю. В. Поляченко, В. Г. Передерій, О. П. Волосовець та ін.]. - К. : Книга плюс, 2005. - 383 с.

5. Сирцов В. К. Особливості підготовки студентів зі спеціальності “Лабораторна діагностика” з курсу гістології, цитології та ембріології / В. К. Сирцов, В. М. Євтушенко // Впровадження засад Болонської системи освіти: український і зарубіжний досвід : матеріали Всеукр. навч.-наук. конф. - Тернопіль, 2007. - С. 46-48.

6. Шулікін Д. Е. Вища освіта України: вдосконалити нормативну базу і підвищити якість / Д. Е. Шулікін // Освіта України. - 2011. - № 13 - 14. - С. 4-5.

Отримано 10.07.15 